\title{
Value of vascular growth factors after stenting coronary arteries in patients with IHD
}

\author{
Dana Taizhanova, Roza Bodaubay
}

No1 Department of Internal Diseases, Karaganda Medical University, Karaganda city, Republic of Kazakhstan

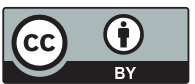

This work is licensed under a Creative Commons Attribution 4.0 International License

Received: 2019-03-13

Accepted: 2019-04-26

UDC: $616.132 .2-07(574)$

\section{J Clin Med Kaz 2019;2(52):6-9}

Corresponding author: Roza Bodaubay, No1 Department of Internal Diseases, Karaganda Medical University. Postal address: 40, Gogol street, Karaganda city, Republic of Kazakhstan.

Tel.: 8-707-873-57-29 E-mail: bodaubayr@mail.ru

\section{ABSTRACT}

One of the most important achievements of medical science is the development and implementation of endovascular methods for treating ischemic heart disease, the volume of which is progressively increasing in relation to other methods of myocardial revascularization. As a result of data from various researchers, the mechanism for the development of coronary artery restenosis in patients with coronary artery disease undergoing endovascular interventions can be an inflammatory reaction, smooth muscle hyperplasia, formation of a wall clot and its organization, as well as the effect of an angiotensin-converting enzyme that activates angiotensin-II, an inducer and inhibits the activity of bradykinin, which inhibits cell growth.

Recent studies of molecular and cellular mechanisms of restenosis in models of vascular damage in animals, as well as histological studies of human coronary arteries, have shown that the basis for the development of restenosis is the activation of migration and proliferation of vascular cells under the influence of growth factors caused by damage, which is a manifestation of angiogenesis and leads to neointima hyperplasia and neoadvention, narrowing the lumen of arteries.

However, today there is no single point of view regarding the role of vascular growth factors in the development of the restenotic process, the number of studies highlighting the dynamics of the concentration of vascular growth factors in response to balloon expansion or implantation of coronary stents, and their possible role in the neointima formation and the restenosis development.

Key words: ischemic heart disease, myocardial infarction, restenosis, platelet growth factor, fibroblast growth factor

\section{ЖУРЕКТІН ИШЕМИЯЛЫҚ АУРУЫМЕН НАУҚАСТАРДА ТӘЖ АРТЕРИЯЛАРЫНА ЖАСАЛҒАН СТЕНТТЕН КЕЙІНГІ ТАМЫРЛЫҚ ӨСУ ФАКТОРЛАРЫНЫН МӘНІ \\ Тайжанова Д.Ж., Бодаубай Р. \\ №1 Ішкі аурулар кафедрасы, Қарағанды медицина университеті, Қарағанды қаласы, Қазақстан Республикасы}

\section{ТҰЖЫРЫМДАМА}

Медицина ғылымы саласындағы ең маңызды жетістіктердің бірі ретінде жүректің ишемиялық ауруын емдеуде эндоваскулярлы әдістердің тәжірбиеге енгізілуі болып табылады. Бұл әдіс басқадай миокардтың ревсакуляризациялық әдістермен салыстырғанда үдемелі түрде ұлғаюда. Әртүрлі зерттеушілердің мәліметтерінің нәтижелеріне сүйенсек, эндоваскулярлы әдіспен емделген жИА-мен науқастарда рестеноздың даму механизмінде қабыну реакциялары, тегісбұлшықетті талшықтар гиперплазиясы, қабырғалық тромбозддардың түзілуі, сондай-ақ ангиотензинайналдырушы фрерменттердің әсерінен ангиотензин-ІІ белсенуінен жасушаның пролиферациясы күшейтіліп, жасушаның өсуін тежейтін брадикинин белсенділігі тежеледі.

Соңғы уақытта рестеноз дамуының молекулярлық және жасушалық механизмдерінің жануарлар моделінде тамырлардың зақымдануын анықтауға байланысты зерттеулер, сондай-ақ адамдардың тәж артериясының гистологиялық зерттеулері нәтижесі көрсеткендей, рестеноз негізінде өсу факторларының әсерінен тамырлық жасушалардың пролиферациясы және миграциясының белсенділенуі жатады. Ол өз кезегінде зақымдану салдарынан ангиогенезге және артерияның қуысының тарылуына алып келетін неоадвентиция, неоинтималық гиперплазияның дамуына алып келеді.

Алайда, бүгінгі күні рестеноздық үдерістің дамуындағы тамырлық өсу факторларының ролі жайлы біріккен көзқарас әліде жоқ, сондайақ рестеноз дамуындағы және неоинтиманың түзілуіне алып келуі мүмкін болатын тәж артерияларын стенттеу немесе баллонды кеңейтуге жауап ретінде тамырлық өсу факторларының концентрациялық динамикасына бағытталған зерттеулер өте аз.

Негізгі сөздер: жүректің ишемиялық ауруы, миокард инфаркті, тромбоцитарлы өсу факторы, фибробласттар өсу факторы 


\section{ЗНАЧЕНИЕ СОСУДИСТЫХ ФАКТОРОВ РОСТА ПОСЛЕ СТЕНТИРОВАНИЯ КОРОНАРНЫХ АРТЕРИЙ У \\ ПАЦИЕНТОВ С ИБС}

Тайжанова Д.Ж., Бодаубай Р.

Кафедра внутренних болезней №1, Медицинский университет город Караганды, Караганда, Республика Казахстан

\section{РЕЗЮМЕ}

В настоящее время применение эндоваскулярных методов в медицинской науке считается одним из важнейших методов лечения болезней системы кровообращения. Несмотря на огромный успех, применение эндоваскулярных методов в клинику, это привело не к столь оптимистичным отдаленным результатам, полученным в первых рандомизированных клинических исследованиях. По материалам различных исследований механизмом развития рестеноза коронарных артерий у больных после стентирования, может развиться воспалительный процесс, вызывая гиперплазию гладкомышечных волокон, формированием пристеночного тромба; указанные процессы соответственно индуцируют клеточную пролиферацию и ингибируют клеточный рост.

Данные проведенных исследований показали, что в основе развития рестеноза лежат молекулярно-клеточные механизмы. Под влиянием факторов роста происходит активация и пролиферации сосудистых клеток, этот процесс в дальнейшем приводит к гиперплазии неоинтимы и неоадвентиции, суживающих просвет артерий.

Однако анализ литературных сведений показывает отсутствие единой точки зрения касательно роли факторов роста в развитии рестеноза коронарных артерий. Дальнейшие исследования по изучению возможной роли факторов роста при фоормировании неоинтимы и развитии рестеноза активно продолжаются во всем мире, в том числе и Казахстане.

Ключевые слова: ишемическая болезнь сердца, инфаркт миокарда, рестеноз, тромбоцитарный фрактор роста, фрактор роста фибробластов

\section{Kipicne}

Бүгінгі таңда жүректің ишемиялық ауруын (ЖИА) эндоваскулярлы емдеуде тәж артерияларын стенттеу жетекші орынды алуды (Erne et al, 2007; Weintraub et al 2008). Алайда, бұл әдістің де кемшіліктері бар, оның әсерінің шектеліне алып келетін фактор, стент ішінде рестеноздың дамуы және ол кейінгі клиникалық нәтижелердің нашарлауына әкеледі. Рестеноздар бұрынғыша 3 - 30\% жағдайда тіркелуде (George D. et al., 2010; Буза В.В., Карпов Ю.А., 2012). Осыған байланысты, тәж артерияларының рестеноздануының жаңа механизмдерін іздестіру, сондай-ақ оны болжамдау өзекті мәселелердің бірі ретінде қалуда.

Стент имплантациясы кезінде тамыр қабырғасының кіші зақымдануы жасушалық және жүйелі қабыну раекцияларының белсенділенуіне алып келетіні дәлелденген. Ол өз кезегінде ота жасалған тамыр сегментінде неоинтиманың түзілуінде маңызды роль атқарады (Бабунашвили А.М. и др., 2004). Рестеноз дамуының жоғарғы қаупі бірқатар қабыну медиаторларының (СРА, ИЛ-6, фибриноген және басқа), және маркерлерінің деңгейінің жоғарлауымен, сондай-ақ қан ұю жүйесінің үрдістерінің белсенділенімен қосарланады (Toutouzas K., et al., 2004; Наумов В.Г. және басқа., 2005; Раимбекова И.Р., 2007; Гринштейн Ю.И., 2009; Габбасов 3.А., 2010; Бернс С.А. және басқа., 2011; Березовская Г.А. және басқа., 2012).

Әртүрлі зерттеушілердің мәліметтері бойынша, өсу факторларымен тығыз байланыстағы атеросклероздық түйіндердің дестабилизациясы және эндотелиальды дисфункцияның аталған үрдістермен айқын байланысының болуында[1].Өсуфакторлары-жоғарыспцификалықақуыздар, қанда өте аз концентрацияда болады және ангиогенезге белсенді қатысады, сондай-ақ эндотелиальды жасушалардың белсенуінде пролиферация және миграция кезінде жасуша арасындағы регуляторлық және координациялық қызметтің орындалуына қатысады [2,3]. Өсу факторлары (PDGF_AB, VEGF, FGF, трансформирлеушіөсу факторы b - TGF b) ангиогенездің негізгі стимуляторлары болып табылады, жасушаның пролиферациясын күшейтеді және бірқатар механикалық және метаболикалық жағдайлардың (созылу немесе деформация, гипоксия және басқа) әсерінен белсенеді $[4,5]$.

Тамыр қабырғаларының механикалық жарақаттануының салдарынан дамыған патофизиологиялық механизмдер, қабынулық, пролиферативті компоненттер және жасушадан тыс матрикстің ремоделирленуін белсендіреді. Бұл үрдістің салдарынан интервенция аймағындағы тамырларыдң окклюзиясы және неоинтимальды гиперплазияның дамуы болып табылады [Welt, Rogers, 2002]. Бұл асқынудың патогенезіндегі ең маңыздысы жергілікті иммундық жауапқа, қан ұюға және тамыр тонусының реттелуіне қатысатын эндотелиальды қызметтің бұзылуынан болады [Behrendt, Ganz, 2002].

Рестеноз дамуында негізгі рольді белсендірілген пероксисомалық пролифераторлар рецепторлары (PPAR $\gamma$ ) [Inoue T. et al., 2011], тромбоцитарлы өсу факторы, эндотелин-1, тромбин, фибробласттар өсу факторы (FGF) болып табылады [Speidl et al., 2010]. Бұл молекулалардың белсенуі және өзара байланысуы тамырлық тегісбұлшықеттік жасушалардың миграциясын және пролиферациясын туындатады.

Инфаркттен кейін кардиосклероз аумағының түзілуі - күрделі және ұзақ жүретін үрдіс, оның ішінде ең жетекші орынды фибробласттар және оның өсу факторлары иеленеді: негізгі фибробласттар өсу факторы(basic fibroblast growth factor ( $\beta F G F)$, трансформирлеуші өсу факторы (transforming growth factor (TGF $\beta 1)$, тромбоцитарлық өсу факторы(platelet derived growth factor (PDGF AA) [6]. Гипргликемиялық жағдайда бұл өсу фаторларының патологиялық белсенділені болады, ол фибробласттар қызметінің өзгеруіне алы келеді: олар өсу факторларын жасушадан тыс өндір бастайды да айналмалы шеңберді түзеді. Нәтижесінде өмірге маңызды нысанамүшелерінің үздіксіз зақымдануы дамиды.

Сау миокардта бұлшықеттік емес жасушалар тобының әртүрі болады, алайда бұларда негізінен фиброласттар басым болады да тіректік құрылым қызметін атқарады. Фиброласттар гликопротеиндер, протеогликандар, эластин, коллагенді өндіру арқылы дәнекер тіннің жасушааралық, жасушаішілік затының түзілуіне қатысады [7,8]; фиброциттар белгілі бір құрылымдық жағдайда жасушааралық затты ұстап тұрады, ал фиброкласттар талшықтардың қаңқасының ремоделденуін қажет еткен жағдайда оның бұзылысына алып келеді. Фибробласттарды осы қасиетінің арқасында талшықты дәнекер тінінің қызметтерінің бірі - репаративті қызметі іске асады [9]. Жарақаттың жазылуында және қабыну кезінде фибробласттардың өсу факторларымен күшейтілетін (bFGF және PDGF), фибробласттар макрофагтармен белсенеді, арықарай олар паралелльді түрде жасушадан тыс матриксті түзе отырып, фибронектин арқылы фибриллярлы құрылымдармен байланысып, зақымдану аймағына белсенді түрде 
миграцияланады. Фибробласттарға коллагенді ыдырататын ферменттер - коллагеназаның болуы тән. Постинфаркттен кейінгі кезеңде дәнекертінді тыртықтың түзілуі кезінде экстрацеллюлярлы матрикстің түзілуіндегі негізгі маңызды компоненттердің бірі коллаген болып табылады. Коллагенді ыдырата және жаңасын түзе отырып, фибробласт оның қайта құрылуына әсер етеді және зақымдану орнында дәнекер тіннің түзілуіне әкеледі [10,11].

Фибробласттар көптеген проангиогенді факторларды түзеді-вазоэндотелиальдыөсуфакторлары,гепатоциттердіңөсу факторлары, PDGF AA, $\beta$-FGF, TGF $\beta 1[12,13]$. Фибробласттар осы тұқымдастықтың басқада түрімен дифференцирлену қабілетімен ерекшеленеді: миофибрбласттарда, адипоцитке ұқсас жасушаларда, хондроциттерде және остеобласттарда $[14,15,16]$. Жасуша арасындағы регуляторлық және координациялық қызметті әртүрлі цитокиндер және қанда өте төмен концентрацияда болатын жоғары спецификалық ақуыздар - өсу факторлары қаматамсыз етеді.

Осыған ұқсас факторларға фибробласттардың өсу факторы жатады (Fibroblast Growth Factor, FGF) - ол жасушаның дифференцировкасында, пролиферациясында және жасушаның қозғалуында қуатты модулятор болып табылады [17]. FGF көптегене пептидтер тобынан тұрады, оның ішінде ең биологиялық маңыздысы фиброгенез индукторы ретінде $\mathrm{bFGF}$ маңызды роль атқарады. bFGF негізгі мөлшері жасушаның цитоплазмасында болады $[18,19]$.

Жасушаның некрозы кезінде цитолитикалық синдромның көлемінің ұлғаюынан bFGF деңгейінің өзгеретіні in vivo дәлелденген [20]. Жануарларға жүргізілген экспериментте, жалған миокард инфарктін туындатқаннан кейін 6 жән 12 сағаттан соң, bFGF деңгейінің қысқа уақытқа қалыпты мәнінен 2 есе жоғарлауы байқалған, бұл цитолиз ферменттерінің концентрациясының (креатинфосфокиназа, гидроксибутиратдегидрогеназа) шыңымен сәйкес келген. 24 сағат өткеннен кейін bFGF құрамы бастапқы көрсеткішке келген. Жүректің қақпақшаларының мезенхимасының түзілуінде bFGF ролі байқалған [21]. Noonan синдромының патогенезін зерттеу кезінде bFGF-ның жүректің туа пайда болған ақауының дамуына қатысатыны анықталған [22], және қазіргі уақытта жүрек қақпақшаларын in vitro өсіруде bFGF ролін зерттеуге бағытталған бірқатар зерттеу жұмыстары бар [23].

FGF белсенділігі әртүрлі факторлармен соның ішінде гепаринмен реттеледі. TGFb1 сондай-ақ көптеген жасушалардың басқада өсу факторларына реакциясын (жасушаның түріне байланысты) басады немесе күшейтеді, олардың дифференцировкасын bFGF белсенділігін реттейді [24], миофибробласттарды белсендіре отырып, жасушааралық матриксте фибриллин ақуызының инкорпорациясын туындатады. Фибробласттардың өсу факторы тегісбұлшықетті жасушалар және эндотелиоциттердің өсуін стимуляциялау арқылы ангиогенезді белсендіреді деген болжам бар [25]; $\alpha \mathrm{FGF}$ аутокринді механизм арқылы әсер етеді. bFGF ишемияланған миокардқа экспрессияланады және коллатеральдардың түзілуінде негізгі роль атқарады деп есептелінеді [26]. Фибробласттар өсу факторының тамырлардың өсуін күшейту қабілеті, миокардтың васкуляризациясын жақсартушы перспективті зат ретінде қарастыруға мүмкіндік береді. Қазіргі уақытта өсу факторын қолдану in vivo және in vitro зерттеу жұмыстары жүргізілуде.

Ресей ғалымдарының дәлелдеуі бойынша, bFGF әсер етуімен некроз аумағында, сондай-ақ аралық аумақта қабынудың инфильтрациялық фазасы айқынырақ байқалады, фибробласттардың фиброциттерге айналу үрдісі бұзылады, зерттеуге алынған жануарлардың интактті миокардында эндотелиоциттердің мөлшері ерте кезеңде жоғарлайды [23]. D.F. Lazarous және басқа авторлардың [27] бақылауы бойынша, bFGF қолданумен жүргізілген емдеуде, 6 айдан кейін қандайда бір құрылымдық немесе вазопролиферативтік әсерге әкелмегені байқалған. K. Sato et al. [28] мәліметтері бойынша, бір реттік интраперикардиальды және интракоронарлы түрде bFGF енгізу миокард және контрактильдігінің жақсаруына әкелген.

2012 жылы сәуір айында американдық ғалымдар кардиомиоцитттердегі фибробласттарды қайәта бағдарламалау бойынша ғылыми тәжірбиелерінің нәтижелерін жариялады. Олар жасуша дақылына тыртық жасушасының үш генін (Gata4, Mef2c и Tbx5) кіргізе алды, мұнда тіннің қайта түзілу үрдісі іске қосылған [29]. Нәтижесінде олар жүрек жұмысына жетісті қатысатын кардиомиоциттерге өте ұқсас, жасушаларда фибробласттарды қайта бағдарлауға қол жеткізді. Сондайақ қазіргі уақытта $\alpha \mathrm{FGF}$ енгізілген ЖИА-мен науқастарды зерттеу жұмыстары жүргізілуде [30].

15 мыңнан астам сау адамның қатысуымен жүргізілген ірі көлемді зерттеу жұмысының мәліметі бойынша IL-6 деңгейінің қалыпты мәннен жоғарлауы, жедел миокард инфарктінің даму қаупін 2-4 есе арттыратыны дәлелденген[31]. IL-6 -ның өндірілуіне FGF әсер етуі, жедел миокард инфарктінің дамуын болжаудағы ерте диагноситкалық бағалау мәніне ие болуы мүмкін.

Disclosures: There is no conflict of interest for all authors.

Мақала авторлары мүдде конфликтісін жоққа шығарады. Бұл шолу мақаласы басқада басылымдарға қаралуға берілмеген және ашық басылымдарға жарияланбаған.

Қаржыландыру. Бұл мақалаға спонсорлық қолдау болған жоқ.

\section{Әдебиеттер}

1. Presta M., Dell'Era P., Mitola S., Moroni E., Ronca R., Rusnati M. Fibroblast growth factor/fibroblast growth factor receptor system in angiogenesis. Cytokine and Growth Factor Reviews. 2005; 16(2):159-178. https://doi.org/10.1016/j.cytogfr.2005.01.004

2. Mignatti P., Rifkin D. B. Biology and biochemistry of proteinases in tumor invasion. Physiol. Rev. 2011; 73:161-195. https:// doi.org/10.1152/physrev.1993.73.1.161

3. Klein S., Giancotti F. G., Presta M., Albelda S. A., Buck C. A., Rifkin D. B. Basic fibroblast growth factor modulates integrin expression in microvascular endothelial cell. Mol. Biol. Cell. 2006; 4:973-982. https://doi.org/10.1091/mbc.4.10.973

4. Carmeliet P. Angiogenesis in life, disease and medicine. Nature. 2005; 438:932-936. https://doi.org/10.1038/nature04478

5. Christian F., Ansel P., Behzad O. FGF23 induces left ventricular hypertrophy. J. Clin. Invest. 2011; 121(11):4393-4408. https:// doi.org/10.1172/JCI46122 
6. Tiyyagura S.R., Pinney S.P. Left ventricular remodeling after myocardial infarction: past, present, and future. Mt. Sinai J. Med. 2006; 73(6):840-851.

7. Flavell S.J., Hou T.Z., Lax S. et al. Fibroblasts as novel therapeutic targets in chronic inflammation. British. J. Pharmacology. 2008; 153:241-246. https://doi.org/10.1038/sj.bjp.0707487

8. Flavell S.J., Hou T.Z., Lax S. et al. Fibroblasts as novel therapeutic targets in chronic inflammation. British. J. Pharmacology. 2008; (153):241-246. https://doi.org/10.1038/sj.bjp.0707487

9. Shurygina I.A., Shurygin M.G., Ajushinova N.I., Kanja O.V. Fibroblasty i ih rol v razvitii soedinitel'noj tkani (Fibroblasts and their role in development of connection tissue) [in Russian]. Sibirskij medicinskij zhurnal. 2012; 3:8-12.

10. Keeley E.C., Mehrad B., Strieter R.M. Fibrocytes: Bringing new insights into mechanisms of inflammation and fibrosis. International J. Biochemistry Cell Biology. 2010; 42:535-542. https://doi.org/10.1016/j.biocel.2009.10.014

11. Hartlapp I., Abe R., Saeed R.W., et al. Fibrocytes induce anangiogenic phenotype in cultured endothelial cells and promote angiogenesis in vivo. FASEB J. 2001; 15:2215-2224. https://doi.org/10.1096/fj.01-0049com

12. Postlethwaite A.E., Shigemitsu H., Kanangat S. Cellular origins of fibroblasts: possible implications for organ fibrosis in systemic sclerosis. Curr. Opin. Rheumatol. 2004; 16:733-738. https://doi.org/10.1097/01.bor.0000139310.77347.9c

13. Moore B.B., Kolodsick J.E., Thannickal V.J., et al. CCR2-mediated recruitment of fibrocytes to the alveolar space after fibrotic injury. Am. J. Pathol. 2005; 166(3):675-684. https://doi.org/10.1016/S0002-9440(10)62289-4

14. Bellini A. The role of the fibrocyte, a bone marrow-derived mesenchymal progenitor, in reactive and reparative fibroses. Lab. Investigation. 2007; 87:858-870. https://doi.org/10.1038/labinvest.3700654

15. Hong K.M., Belperio J.A., Keane M.P., et al. Differentiation of human circulating fibrocytes as mediated by transforming growth factor-beta and peroxisome proliferator-activated receptor gamma. J. Biol. Chem. 2007; 282:22910-22920. https://doi. org/10.1074/jbc.M703597200

16. Choi Y.H., Burdick M.D., Strieter R.M. Human circulating fibrocytes have the capacity to differentiate osteoblasts and chondrocytes. International J. Biochemistry Cell Biology. 2010; 42:662-671. https://doi.org/10.1016/j.biocel.2009.12.011

17. Shurygin M.G., Dremina N.N., Malyshev V.V., Shurygina I.A. Kolichestvennaja gistopatologija infarkta miokarda pri vozdejstvii osnovnogo faktora rosta fibroblastov (Quantitative histopathology of myocardial infarction at the effect of primary fibroblasts growth factor) [in Russian]. Bjulleten' VSNC SO RAMN. 2006; 5(51)

18. Lijnen P.J., Petrov V.V.,.Fagard R.H Collagen production in cardiac fibroblasts during inhibition of angiotensin-converting enzyme and aminopeptidases. J. Hypertens. 2004; 22(1):209-216. https://doi.org/10.1097/00004872-200401000-00031

19. Buziashvili Ju.I., Picano E., Ambat'ello S.G., Mackeplishvili S.T. Angiogenez kak anti ishemicheskij mehanizm (Angiogenesis as anti-ischemic mechanism) [in Russian]. Kardiologija. 2000; (12):82-86.

20. Shurygin M.G., Shurygina I.A. Faktor rosta fibroblastov kak stimuljator angiogeneza pri infarkte miokarda (Fibroblasts growth factor as angiogenesis stimulator at myocardial infarction) [in Russian]. Bjulleten' so ramn. 2010; 30(6).

21. Uhlen, P., Burch, P. M., Zito, C. I., Estrada, M., Ehrlich, B. E. and Bennett, A. M. Gain-of-function/Noonan syndrome SHP-2/ Ptpn11 mutants enhance calcium oscillations and impair NFAT signaling. Proc. Natl. Acad. Sci. 2006; 103:2160-2165. https:// doi.org/10.1073/pnas.0510876103

22. Narine K, De Wever O, Van Valckenborgh D, Francois K, Bracke M, DeSmet S, Mareel M, Van Nooten G. Growth factor modulation of fibroblast proliferation, differentiation, and invasion: implications for tissue valve engineering. Tissue Eng. 2006; 12(10):2707-16. https://doi.org/10.1089/ten.2006.12.2707

23. Zhao Z, Rivkees SA. Programmed cell death in the developing heart: regulation by BMP4 and FGF2. Dev Dyn. 2000; 217:388400 https://doi.org/10.1002/(SICI)1097-0177(200004)217:4<388::AID-DVDY6>3.0.CO;2-N

24. Kissin EY, Lemaire R, Korn JH, Lafyatis R. Transforming growth factor beta induces fibroblast fibrillin-1 matrix formation. Arthritis Rheum. 2002; 46(11):3000-9 https://doi.org/10.1002/art.10621

25. Conway E.M., Collen D., Carmeliet P. Molecular mechanisms of blood vessel growth. Cardiovasc. Res. 2001; 9(3):507-521. https://doi.org/10.1016/S0008-6363(00)00281-9

26. Methods of use of fibroblast growth factor, vascular endothelial growth factor and related proteins in the treatment of acute and chronic heart disease. 2001

27. Lazarous D.F., Scheinowitz M., Shou M. et al. Effects of chronic systemic administration of basic fibroblast growth factor on collateral development in the canine heart. Circulation. 1995; 91(1):145-153. https://doi.org/10.1161/01.CIR.91.1.145

28. Sato K., Laham R.J., Pearlman J.D. et al. Efficacy of intracoronary versus intravenous FGF-2 in a pig model of chronic myocardial ischemia. Ann. Thorac. Surg. 2000; 70(6):2113-2118. https://doi.org/10.1016/S0003-4975(00)02018-X

29. Srivastava D. Transforming scar tissue into beating hearts: the next installment. Frontiers in CardioVascular Biology. 2012

30. Stewart D.J., A phase 2, randomized, multicenter, 26-week study to assess the efficacy and safety of BIOBYPASS (AdGV -VEG121.10) delivered through minimally invasive surgery vesus maximum medical treatment in patients with severe angina, advanced coronary artery disease, and no options for revascularization. Circulation. 2002; 106:2986-a.

31. Alexandraki J. Inflammatory process in type 2 diabetes: the role of cytokines. Ann. N.Y. Acad. Sci. 2006; 1084: 89-117. https:// doi.org/10.1196/annals.1372.039

How to cite this article: Dana Taizhanova, Roza Bodaubay. Value of vascular growth factors after stenting coronary arteries in patients with IHD [in Kazakh]. J Clin Med Kaz. 2019; 2(52):6-9 